\title{
Probing horseradish peroxidase catalyzed degradation of azo dye from tannery wastewater
}

\author{
Sadhanandam Preethi, Ayyappan Anumary, Meiyazhagan Ashokkumar and Palanisamy Thanikaivelan*
}

\begin{abstract}
Biocatalysis based effluent treatment has outclassed the presently favored physico-chemical treatments due to nil sludge production and monetary savings. Azo dyes are commonly employed in the leather industry and pose a great threat to the environment. Here, we show the degradation of $\mathrm{C}$. I. Acid blue 113 using horseradish peroxidase (HRP) assisted with $\mathrm{H}_{2} \mathrm{O}_{2}$ as a co-substrate. It was observed that $0.08 \mathrm{U}$ HRP can degrade $3 \mathrm{~mL}$ of $30 \mathrm{mg} / \mathrm{L}$ dye up to $80 \%$ within $45 \mathrm{~min}$ with the assistance of $14 \mu \mathrm{L}$ of $\mathrm{H}_{2} \mathrm{O}_{2}$ at $\mathrm{pH} 6.6$ and $30^{\circ} \mathrm{C}$. The feasibility of using the immobilized HRP for dye degradation was also examined and the results show up to $76 \%$ dye degradation under similar conditions to that of free HRP with the exception of longer contact time of $240 \mathrm{~min}$. Recycling studies reveal that the immobilized HRP can be recycled up to 3 times for dye degradation. Kinetics drawn for the free HRP catalyzed reaction marked a lower $K_{\mathrm{m}}$ and higher $V_{\max }$ values, which denotes a proper and faster affinity of the enzyme towards the dye, when compared to the immobilized HRP. The applicability of HRP for treating the actual tannery dye-house wastewater was also demonstrated.
\end{abstract}

Keywords: Biocatalysis; Immobilization; Wastewater; Kinetics; Recycling

\section{Background}

Synthetic dyes are extensively used in a variety of industries including leather and textiles. Conversion of skin into leather generates huge quantity of wastewater comprising a mixture of biogenic matter of skins and a large variety of organic and inorganic chemicals. Wastewater from tanneries usually contains high concentrations of dyes, neutral salts, aliphatic and aromatic polymeric substances as well as poly-phenols (Murugananthan et al. 2004). Acid azo dyes are much frequently used and are potentially toxic if left untreated and there is a high risk to the natural flora (Mohan et al. 2005). The chemical constituents of the dye are mainly phenolic compounds. Since these dye molecules are often toxic and hard to degrade in the conventional wastewater treatment systems, urgency for proper treatment of the colored effluent is required.

Although a variety of physico-chemical treatments such as adsorption, precipitation, chemical degradation, electrochemical, photochemical, etc. is available to decolorize the dye-house wastewater, they have inherent disadvantages

\footnotetext{
* Correspondence: thanik8@yahoo.com

Advanced Materials Laboratory, Center for Leather Apparel \& Accessories Development, Central Leather Research Institute (Council of Scientific and Industrial Research), Adyar, Chennai 600 020, India
}

such as demand for an external reagent, large sludge generation, and are expensive and tedious (Gozmen et al. 2009; Sauer et al. 2006; Rodriguez et al. 2010; Lachheb et al. 2002). Hence, alternative treatment processes based on biotechnological principles have gained popularity in recent years (Palmieri et al. 2005; Ollikka et al. 1993). Enzymatic treatment systems are simpler and easy to operate in comparison to the microbial treatment systems (Mohan et al. 2005; Kandelbauer et al. 2004). The catalytic action of enzymes is efficient, selective, have higher reaction rates and require mild reaction conditions compared to chemical catalysts. Oxidative enzymes such as lignin peroxidase, horseradish peroxidase (HRP), manganese peroxidase and phenoloxidase (laccase) are extensively employed to remove color from effluent by oxidative degradation of colored compounds and to degrade toxic polyphenols, polyaromatic hydrocarbons, polychlorinated biphenyls, etc. (Mohan et al. 2005; Ollikka et al. 1993; Kandelbauer et al., 2004; Regalado et al. 2004). Reduction of peroxides at the expense of electron donating substrates makes peroxidases useful in oxidative breakdown of synthetic azo dyes (Regalado et al. 2004).

HRP (EC: 1.11.1.7) is known to degrade a wide spectrum of aromatic compounds such as phenols, anilines as well as dyes in the presence of $\mathrm{H}_{2} \mathrm{O}_{2}$ (Mohan et al. 2005; 
Wagner and Nicell 2001; Ulson de Souza et al. 2007; Onder et al. 2011; Arslan 2011; Gholami-Borujeni et al. 2011). The enzyme has relatively high thermal stability and wide distribution (Regalado et al. 2004). $\mathrm{H}_{2} \mathrm{O}_{2}$ helps to oxidize the enzyme into a catalytically active form that is capable of reacting with the phenolic contaminant. Peroxidases act by generating free-radical compounds followed by spontaneous polymerization, the polymers can then be removed from the aqueous phase (Wagner and Nicell 2001). The use of immobilized HRP for treating effluent is becoming popular since it can offer long lifetime, stability and recyclability (Mohan et al. 2005; Arslan 2011; Alemzadeh and Nejati 2009). However, appropriate selection of encapsulation material specific to the enzyme and optimization of process conditions is still a challenge (Mohan et al. 2005). Here, we show the ability of HRP both in its free and immobilized form to decolorize an industrially important azo dye, C.I. Acid blue 113. Various parameters such as pH, temperature, contact time, $\mathrm{H}_{2} \mathrm{O}_{2}$ and $\mathrm{HRP}$ concentration, and dye concentration have been investigated to optimize the treatment conditions. Further, the immobilized HRP performance was evaluated in the process of dye removal along with its recyclability. The enzyme kinetics and ability to treat real tannery effluent were also examined.

\section{Experimental Materials}

HRP was procured from M/s Medox Biotech Pvt. Ltd., Chennai. $1 \mu \mathrm{L}$ of the enzyme solution contained $10 \mathrm{U}$. Specific activity was $>250$ Pur U/mg. $0.1 \mathrm{M}$ phosphate buffer was prepared using sodium, potassium salts and their respective bases and used to dilute the enzyme such that $2 \mu \mathrm{L}$ solution contains $0.08 \mathrm{U}$ of HRP. $\mathrm{H}_{2} \mathrm{O}_{2}$ used was of analytical grade $(30 \% \mathrm{w} / \mathrm{v})$. The buffers and other chemical reagents used in this study were of laboratory grade. Commercial C. I. Acid Blue 113 was procured from the Leather Processing Division of Central Leather Research Institute, Chennai and its chemical properties are presented in Table 1. Standard solutions of the dye were prepared by dissolving a known quantity of C.I. Acid Blue113 in distilled water. The $\mathrm{pH}$ of the dye solution was 6.6. $\lambda_{\max }$ for C.I.Acid Blue 113 was found to be

Table 1 Chemical properties of C.I. Acid Blue 113 (Colour index number 26360)

\begin{tabular}{ll}
\hline Properties & Value \\
\hline Molecular formula & $\mathrm{C}_{32} \mathrm{H}_{21} \mathrm{~N}_{5} \mathrm{Na}_{2} \mathrm{O}_{6} \mathrm{~S}_{2}$ \\
Molecular structure & \\
Molecular weight & 681.65 \\
Water solubility & $40 \mathrm{mg} / \mathrm{mL}$ \\
Chromophore & Diazo \\
$\lambda_{\text {max }}$ & $566 \mathrm{~nm}$ \\
\hline
\end{tabular}

$566 \mathrm{~nm}$ and the molar extinction coefficient was calculated as $16484.31 \mathrm{~mol}^{-1} \mathrm{~cm}^{-1}$ using Beer-Lambert law.

\section{Optimization of process parameters for the removal of color using free HRP}

Optimization of various process parameters such as $\mathrm{pH}$, temperature, contact time, $\mathrm{H}_{2} \mathrm{O}_{2}$, $\mathrm{HRP}$ concentration and dye concentration was carried out. Batch reactions were conducted at room temperature maintained at $30^{\circ} \mathrm{C}$ using borosilicate vials of $15 \mathrm{~mL}$ capacity. Each reaction mixture consisted of $3 \mathrm{~mL}$ of $30 \mathrm{mg} / \mathrm{L}$ dye, $14 \mu \mathrm{L}$ of $\mathrm{H}_{2} \mathrm{O}_{2}$ and $0.08 \mathrm{U}$ HRP for all the test series except during dye, $\mathrm{H}_{2} \mathrm{O}_{2}$ and HRP optimization. The vials containing the reaction mixture were not subjected to stirring or any kind of agitation. The reaction mixture displayed a $\mathrm{pH}$ of 6.6. Dye decolorization was measured spectrophotometrically using a UV-Visible spectrophotometer (Model UV-160A; Shimadzu) based on the absorbance at $566 \mathrm{~nm}\left(\lambda_{\max }\right)$. Similar experiments were performed by varying the contact time $(0,15,30,45,60,75,90$, $105,120 \mathrm{~min}), \mathrm{pH}(4,5,6.6,8,9,10)$, HRP concentration $(0.02,0.04,0.06,0.08,0.10,0.12 \mathrm{U}), \mathrm{H}_{2} \mathrm{O}_{2}$ concentration $(2,4,6,8,12,14,16,20 \mu \mathrm{L})$, temperature $(20$, $\left.30,40,50,60^{\circ} \mathrm{C}\right)$ and dye concentration $(20,25,30,35$, 40, 45, $50 \mathrm{mg} / \mathrm{L})$. Experiments were performed in triplicate and the mean values of the results are presented along with error bars. For the $\mathrm{pH}$ optimization studies, diluted $\mathrm{HCl}$ and $\mathrm{NaOH}$ were used to adjust the $\mathrm{pH}$ of the samples. The percentage color removal was calculated using the following equation.

$$
\% \text { Color degradation }=\frac{A_{0}-A_{T}}{A_{0}} \times 100
$$

Where $A_{O}$ is the absorbance of the dye solution before enzymatic treatment at $566 \mathrm{~nm} A_{T}$ is the absorbance of the dye solution after enzymatic treatment at $566 \mathrm{~nm}$.

\section{Immobilization of HRP}

$0.08 \mathrm{U}$ of HRP was added to $1 \mathrm{~mL}$ of $0.02 \mathrm{~g} / \mathrm{mL}$ sodium alginate solution and mixed well. The mixture was dropped into $50 \mathrm{~mL}$ of $0.1 \mathrm{M}$ calcium chloride solution through a pipette to form beads while the bottom of the flask was continuously shaken. The beads were left undisturbed in calcium chloride solution to attain stability at $30^{\circ} \mathrm{C}$ for $40 \mathrm{~min}$. The beads were then filtered and used for further studies.

\section{Optimization of process parameters for the removal of color using immobilized HRP}

Optimization of various process parameters such as contact time, temperature, $\mathrm{H}_{2} \mathrm{O}_{2}$ and $\mathrm{HRP}$ concentration was carried out. Batch reactions were conducted at room temperature maintained at $30^{\circ} \mathrm{C}$ using borosilicate vials 
of $15 \mathrm{~mL}$ capacity. Each reaction mixture consisted of $3 \mathrm{~mL}$ of $30 \mathrm{mg} / \mathrm{L}$ dye, $14 \mu \mathrm{L}$ of $\mathrm{H}_{2} \mathrm{O}_{2}$ and $0.08 \mathrm{U}$ of immobilized HRP for all the test series except during $\mathrm{H}_{2} \mathrm{O}_{2}$ and HRP optimization. The vials containing the reaction mixture were not subjected to stirring or any kind of agitation. The reaction mixture displayed a $\mathrm{pH}$ of 6.6. Dye decolorization was measured spectrophotometrically using a UV-Visible spectrophotometer (Model UV-160A; Shimadzu) based on the absorbance at $566 \mathrm{~nm}$ $\left(\lambda_{\max }\right)$. Similar experiments were performed by varying the contact time $(0,15,30,60,90,130,180,210,240$, $270 \mathrm{~min})$, immobilized HRP concentration $(0.02,0.04$, $0.06,0.08,0.10,0.12 \mathrm{U}), \mathrm{H}_{2} \mathrm{O}_{2}$ concentration $(4,8,12,14$, $16,20 \mu \mathrm{L})$ and temperature $\left(4,30,50^{\circ} \mathrm{C}\right)$. Experiments were performed in triplicate and the mean values of the results are presented along with error bars.

\section{Recycling studies for the removal of color using immobilized HRP}

Each reaction mixture consisted of $3 \mathrm{~mL}$ of $30 \mathrm{mg} / \mathrm{L}$ dye, $14 \mu \mathrm{L}$ of $\mathrm{H}_{2} \mathrm{O}_{2}$ and $0.08 \mathrm{U}$ of immobilized HRP were kept for different time intervals from 60 to $240 \mathrm{~min}$ at $30^{\circ} \mathrm{C}$ and $\mathrm{pH} 6.6$ for the first cycle experiments. The extent of decolorization after each point of time was analyzed spectrophotometrically as above. Experiments were performed in triplicate and the mean values of the results are presented along with error bars. After the experiments, the beads were collected, washed and reused for the second and third cycle of experiments.

\section{Enzyme kinetics}

The kinetic experiments for the free HRP were performed by varying the concentration of dye (20, 30, 40 and $50 \mathrm{mg} / \mathrm{L})$ and the contact time $(15,30,45,60,75 \mathrm{~min})$ using constant free enzyme and $\mathrm{H}_{2} \mathrm{O}_{2}$ concentration under the optimum conditions at $\mathrm{pH} 6.6$ and $30^{\circ} \mathrm{C}$ (see Additional file 1). Similarly, the kinetic experiments for the immobilized HRP were performed by varying the concentration of dye $(20,30,40$ and $50 \mathrm{mg} / \mathrm{L})$ and the contact time $(25,85,125,200 \mathrm{~min})$ using constant immobilized enzyme and $\mathrm{H}_{2} \mathrm{O}_{2}$ concentration under the optimum conditions at $\mathrm{pH} 6.6$ and $30^{\circ} \mathrm{C}$ (see Additional file 1). The maximum rate of decolorization reaction $\left(V_{\max }\right)$ and Michaelis-Menten constant $\left(K_{\mathrm{m}}\right)$ of free as well as immobilized HRP were determined by linear regression and the Lineweaver - Burk plots.

\section{Results and discussion}

\section{Optimization of process parameters using free HRP}

Initial experiments were performed to determine the optimum contact time required to degrade the dye using free HRP. A series of experiments with $3 \mathrm{~mL}$ of $30 \mathrm{mg} / \mathrm{L}$ dye, $14 \mu \mathrm{L}$ of $\mathrm{H}_{2} \mathrm{O}_{2}$ and $0.08 \mathrm{U}$ free HRP were conducted for different time intervals up to $120 \mathrm{~min}$ at $30^{\circ} \mathrm{C}$ and $\mathrm{pH}$ 6.6. For every $15 \mathrm{~min}$, one vial was analyzed for the dye concentration using UV-Visible spectrophotometer as described above. It is seen from Figure 1a that there is a significant increase in the degradation of dye up to $45 \mathrm{~min}$ of contact time. After $45 \mathrm{~min}$, no substantial improvement in the degradation of dye was observed. Hence, subsequent experiments were carried out for $45 \mathrm{~min}$ as contact time. Temperature is another important parameter governing the action of enzymes. Experiments were carried out using $3 \mathrm{~mL}$ of $30 \mathrm{mg} / \mathrm{L}$ dye, $14 \mu \mathrm{L}$ of $\mathrm{H}_{2} \mathrm{O}_{2}$ and $0.08 \mathrm{U}$ free HRP and kept for different temperatures from 20 to $60^{\circ} \mathrm{C}$ for $45 \mathrm{~min}$ at $\mathrm{pH}$ 6.6. The extent of degradation of dye as a function of temperature is shown in Figure 1b. It is evident that the maximum color removal is achieved at lower temperature. It has been shown that free HRP has maximum activity at temperatures as low as $5^{\circ} \mathrm{C}$ (Shi et al. 2011). Although we found that the maximum color removal is achieved at $20^{\circ} \mathrm{C}$, we have carried out all further experiments in this study at room temperature $\left(30^{\circ} \mathrm{C}\right)$ considering the practical limitations on the application of this technology.

The relation between the concentration of enzyme and substrate is important in achieving maximum catalytic activity of the enzyme. In order to find the optimum enzyme dosage for the chosen dye concentration, various experiments were performed with $3 \mathrm{~mL}$ of $30 \mathrm{mg} / \mathrm{L}$ dye and $14 \mu \mathrm{L}$ of $\mathrm{H}_{2} \mathrm{O}_{2}$ with varying dosage of free HRP from 0.02 to $1.12 \mathrm{U}$ for $45 \mathrm{~min}$ at $\mathrm{pH} 6.6$ and $30^{\circ} \mathrm{C}$ and the results are shown in Figure 2a. It is seen that the degradation of color is increasing as the concentration of HRP increases and attain saturation at $0.08 \mathrm{U}$. Further increase in the dosage of HRP did not result in pronounced color removal. Hence, optimum HRP concentration is finalized as $0.08 \mathrm{U}$ and used in all the subsequent experiments. To find the optimum $\mathrm{H}_{2} \mathrm{O}_{2}$ concentration, various experiments were performed with $3 \mathrm{~mL}$ of $30 \mathrm{mg} / \mathrm{L}$ dye and $0.08 \mathrm{U}$ free HRP with varying concentration of $\mathrm{H}_{2} \mathrm{O}_{2}$ from 2 to $20 \mu \mathrm{L}$ for $45 \mathrm{~min}$ at $\mathrm{pH} 6.6$ and $30^{\circ} \mathrm{C}$ and the results are shown in Figure $2 \mathrm{~b}$. It is seen that the degradation of dye is very low $(\sim 42 \%)$ at low concentration of $\mathrm{H}_{2} \mathrm{O}_{2}$. However, a further increase in concentration of $\mathrm{H}_{2} \mathrm{O}_{2}$ resulted in pronounced increase in the degradation of dye reaching up to $78 \%$, which underscores the role of $\mathrm{H}_{2} \mathrm{O}_{2}$ on the catalytic activity of HRP. Saturation of dye degradation is noted after $14 \mu \mathrm{L} \mathrm{H}_{2} \mathrm{O}_{2}$, which was selected as an optimum concentration and used in all the subsequent experiments.

$\mathrm{pH}$ is an important factor for the activity of any enzyme and in particular for HRP. To find the optimum $\mathrm{pH}$ for the HRP to degrade the dye, various experiments were performed with $3 \mathrm{~mL}$ of $30 \mathrm{mg} / \mathrm{L}$ dye, $14 \mu \mathrm{L}$ of $\mathrm{H}_{2} \mathrm{O}_{2}$ and $0.08 \mathrm{U}$ free $\mathrm{HRP}$ with varying $\mathrm{pH}$ conditions from 4 to 10 for $45 \mathrm{~min}$ at $30^{\circ} \mathrm{C}$ and the results are shown in Figure 3a. It is seen that the free HRP exhibits higher percentage of 
(a)

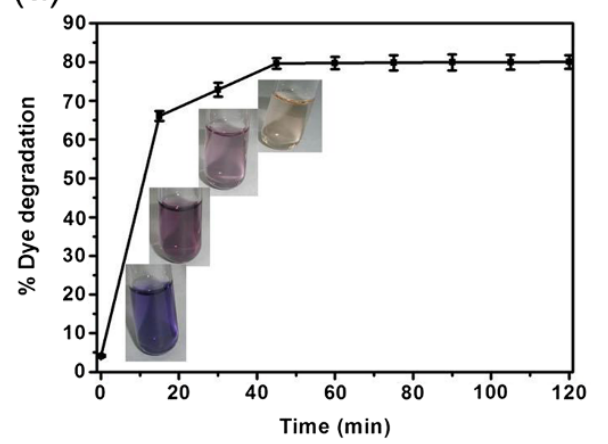

(b)

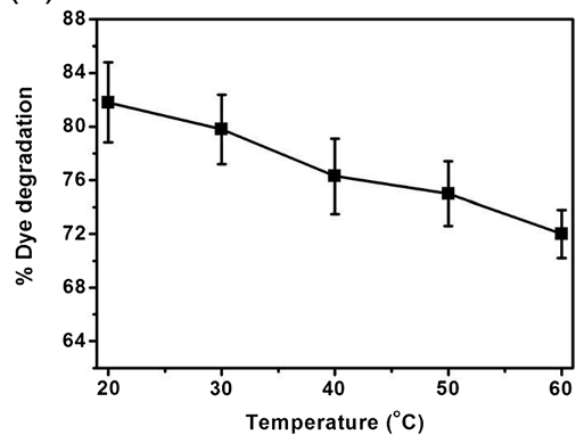

Figure 1 Effect of (a) time and (b) temperature on the free HRP catalyzed color removal. Inset in Figure 1 (a) shows the photographs of dye solution during the course of HRP treatment up to $45 \mathrm{~min}$.

color removal at various $\mathrm{pH}$ values such as 4, 6.6 and 9. It is known that free HRP has higher activity on a wide $\mathrm{pH}$ range (Onder et al. 2011; Shi et al. 2011). Hence, we have chosen $\mathrm{pH} 6.6$ as the optimum $\mathrm{pH}$ and used in all the subsequent experiments. Concentration of the substrate is another important factor, which will affect the performance of the enzymatic reaction. To determine the optimum substrate concentration, experiments were performed with $14 \mu \mathrm{L}$ of $\mathrm{H}_{2} \mathrm{O}_{2}$ and $0.08 \mathrm{U}$ free HRP with $3 \mathrm{~mL}$ of different dye concentrations from 20 to $45 \mathrm{mg} / \mathrm{L}$ for $45 \mathrm{~min}$ at $\mathrm{pH} 6.6$ and $30^{\circ} \mathrm{C}$ and the results are shown in Figure $3 \mathrm{~b}$. As we can see from Figure $3 \mathrm{~b}$, the degradation of dye is higher at low concentration of dye from 20 to $30 \mathrm{mg} / \mathrm{L}$. Beyond which, the degradation of dye is decreasing abruptly as the concentration of dye increases. Hence, the optimum substrate concentration was fixed as $30 \mathrm{mg} / \mathrm{L}$ for all the subsequent experiments.

\section{Optimization of process parameters using immobilized HRP}

Immobilization of enzyme is an important technique to reduce the cost of enzymatic processes as it helps in recovery and recycling of entrapped enzymes for more than one cycle of reaction. Here, we have immobilized the free HRP in calcium alginate beads and experiments were performed to optimize the process parameters for the application of immobilized HRP for decolorizing C.I. Acid Blue113. In order to optimize the contact time, experiments with $3 \mathrm{~mL}$ of $30 \mathrm{mg} / \mathrm{L}$ dye, $14 \mu \mathrm{L}$ of $\mathrm{H}_{2} \mathrm{O}_{2}$ and $0.08 \mathrm{U}$ immobilized HRP were kept for different time intervals up to $270 \mathrm{~min}$ at $30^{\circ} \mathrm{C}$ and $\mathrm{pH}$ 6.6. The extent of decolorization as a function of time is shown in Figure 4a. A gradual increase in the degradation of dye is noticed as the contact time increases. In comparison to free HRP (45 min), significantly high contact time (240 $\mathrm{min})$ is required for immobilized HRP to degrade the dye appreciably. This may be due to the entrapment of HRP in the calcium alginate beads. To find the optimum temperature, various experiments were performed with $3 \mathrm{~mL}$ of $30 \mathrm{mg} / \mathrm{L}$ dye, $14 \mu \mathrm{L}$ of $\mathrm{H}_{2} \mathrm{O}_{2}$ and and $0.08 \mathrm{U}$ immobilized HRP at different temperatures from 4 to $50^{\circ} \mathrm{C}$ for $240 \mathrm{~min}$ at $\mathrm{pH}$ 6.6. The results are shown in Figure 4b. Akin to free HRP, the extent of dye degradation is significantly reduced as the temperature of the reaction increases. However, all the further experiments were conducted at room temperature $\left(30^{\circ} \mathrm{C}\right)$ considering (a)

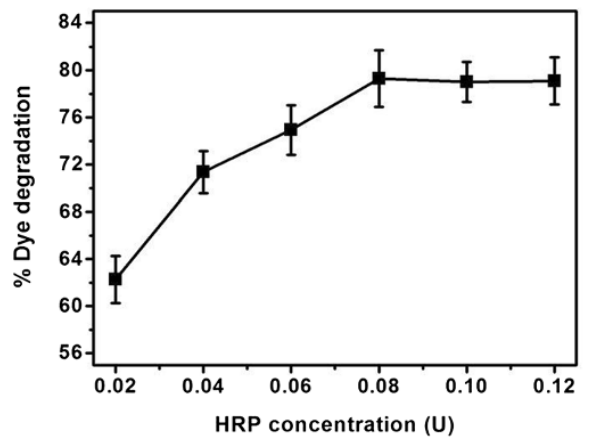

(b)

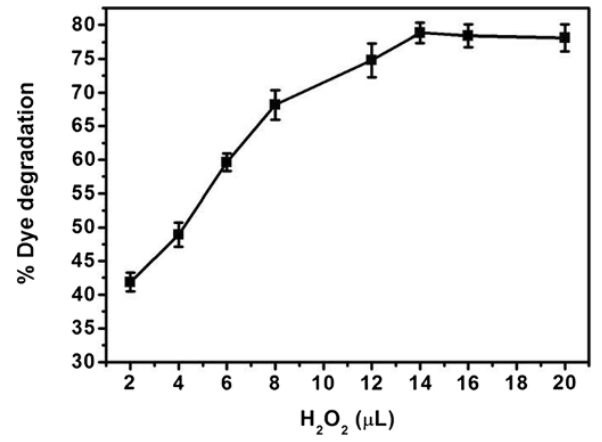

Figure 2 Effect of (a) enzyme and (b) $\mathrm{H}_{2} \mathrm{O}_{2}$ concentration on the free HRP catalyzed color removal. 
(a)

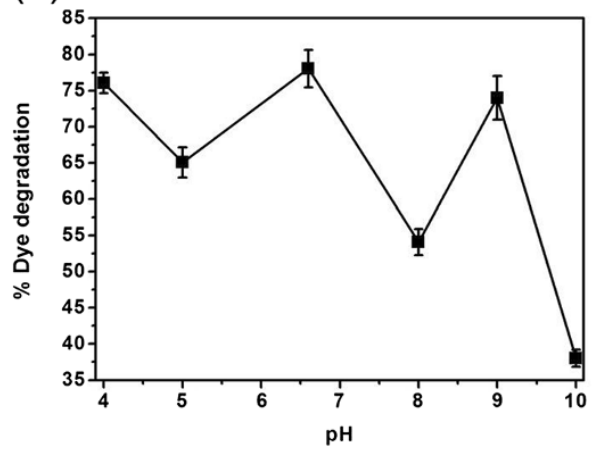

(b)

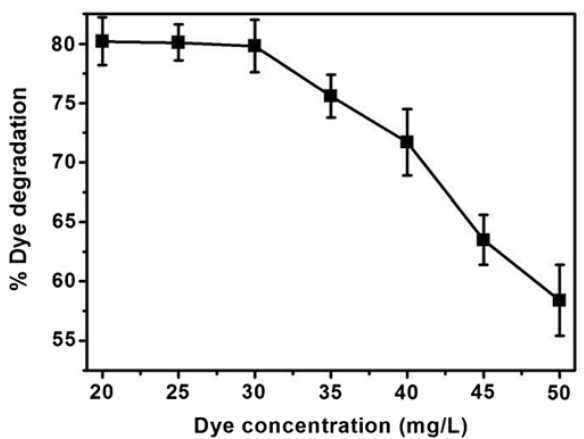

Figure 3 Effect of (a) pH and (b) dye concentration on the free HRP catalyzed color removal.

the practical feasibility. To find the optimum immobilized HRP concentration for degrading the dye, various experiments were performed with $3 \mathrm{~mL}$ of $30 \mathrm{mg} / \mathrm{L}$ dye and $14 \mu \mathrm{L}$ of $\mathrm{H}_{2} \mathrm{O}_{2}$ with varying immobilized $\mathrm{HRP}$ concentration for $240 \mathrm{~min}$ at $\mathrm{pH} 6.6$ and $30^{\circ} \mathrm{C}$ and the results are shown in Figure 5a. It is seen that the extent of dye degradation increases as the concentration of immobilized HRP increases reaching saturation at $0.08 \mathrm{U}$. This value is similar to that observed for free HRP. In order to find the optimum $\mathrm{H}_{2} \mathrm{O}_{2}$ concentration, experiments were performed with $3 \mathrm{~mL}$ of $30 \mathrm{mg} / \mathrm{L}$ dye and $0.08 \mathrm{U}$ immobilized HRP with varying concentration of $\mathrm{H}_{2} \mathrm{O}_{2}$ from 4 to $20 \mu \mathrm{L}$ for $240 \mathrm{~min}$ at $\mathrm{pH} 6.6$ and $30^{\circ} \mathrm{C}$ and the results are shown in Figure $5 \mathrm{~b}$. It is observed that the dye degradation reaches maximum at $14 \mu \mathrm{L} \mathrm{H}_{2} \mathrm{O}_{2}$ beyond which there is no significant increase. This trend is also not very different from free HRP.

\section{Recyclability of immobilized HRP}

An important advantage of immobilized enzymes is their recyclability in the process thereby reducing the cost of treatment. Hence, we have examined the recycling ability of immobilized HRP for the color removal and the results are shown in Figure 6. It is seen that immobilized HRP can be recycled for at least 3 cycles without losing much of its activity. The color removal efficiency of immobilized HRP followed similar pattern for all the 3 cycles as a function of time. There seems to be a marginal reduction in the extent of decolorization during the 2nd and 3rd cycle of experiments. Hence, it is demonstrated that the immobilized HRP can reduce the cost of color removal at industrial level applications.

\section{Kinetics of free and immobilized HRP}

The kinetics were obtained by observing the degradation of different concentrations of dye at specified time intervals using optimized $\mathrm{H}_{2} \mathrm{O}_{2}$ concentration and free as well as immobilized HRP concentration under the optimum conditions (at $\mathrm{pH} 6.6,30^{\circ} \mathrm{C}$ ). Lineweaver-Burk plots (double reciprocal plot) were made for both free and immobilized HRP as shown in Figure 7 . The slope $\left(K_{\mathrm{m}} / V_{\max }\right)$ and intercept $\left(1 / V_{\max }\right)$ values were obtained from the plots in order to calculate the apparent Michaelis-Menten constant $\left(K_{\mathrm{m}}\right)$ as well as the maximum rate of the reaction $\left(V_{\max }\right)$. The calculated value of the apparent $K_{\mathrm{m}}$ for free HRP is $0.068 \mathrm{mmol} / \mathrm{l}$, which is lower than immobilized HRP $(0.425 \mathrm{mmol} / \mathrm{l})$. Also, the calculated value of $V_{\max }$ for free HRP is $0.067 \mathrm{mmol} / \mathrm{l} . \mathrm{min}$, which is higher than (a)

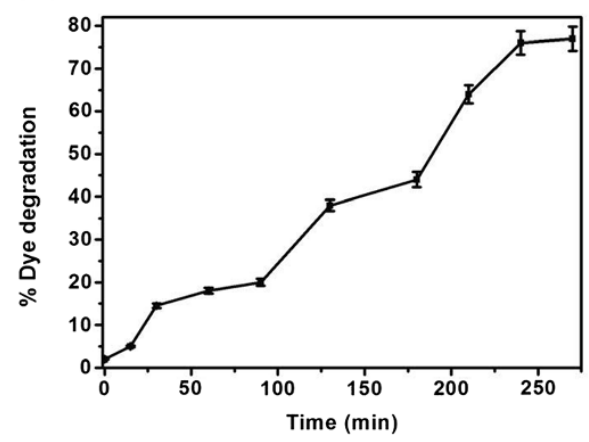

(b)

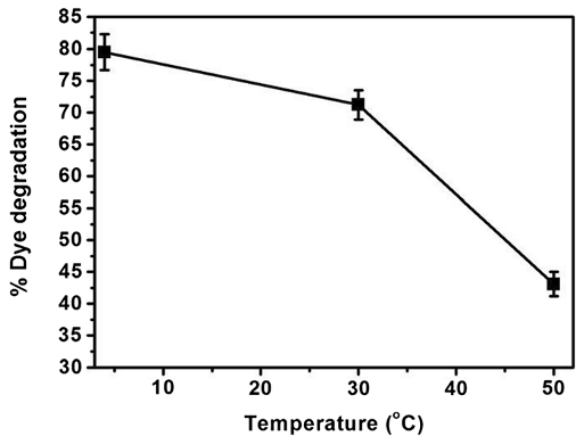

Figure 4 Effect of (a) time and (b) temperature on the biocatalytic color removal using immobilized HRP. 
(a)

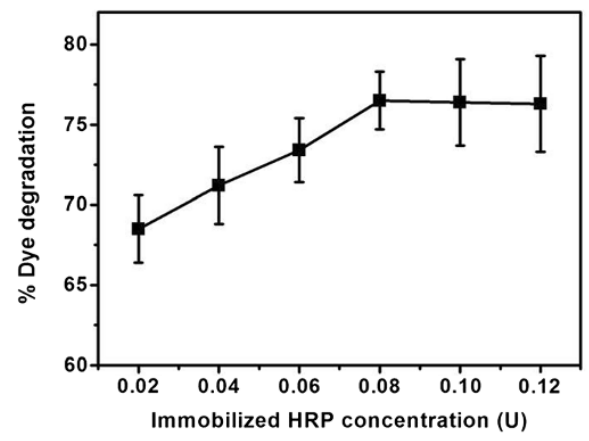

(b)

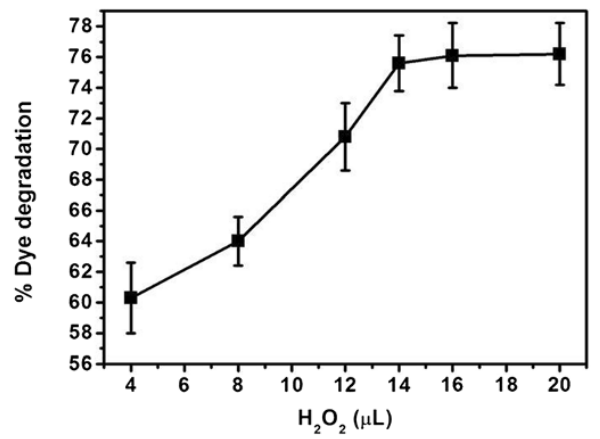

Figure 5 Effect of (a) enzyme and (b) $\mathrm{H}_{2} \mathrm{O}_{2}$ concentration on the biocatalytic color removal using immobilized HRP.

immobilized HRP (0.048 mmol/l.min). In general, lower $K_{\mathrm{m}}$ means better binding of the enzyme to its substrate and higher $V_{\max }$ indicates faster reaction. Kinetics calculated in this study shows higher affinity of free HRP (low $K_{\mathrm{m}}$ ) for the degradation of the dye. Higher apparent $K_{\mathrm{m}}$ and lower $V_{\max }$ values obtained for the immobilized HRP suggest that the immobilization of HRP leads to a lower affinity for the substrate. This may be due to the reduced enzyme activity in immobilized enzyme sample. Such observations are also noted in the previous studies (Monier et al. 2010).

\section{Decolorization of tannery effluent using free HRP}

In order to look at the efficiency of the free HRP for degrading the dye in tannery effluent, which is a mixture of dye and chemicals such as formic acid, aromatic polymers and fat liquors generally used for making leather, we have used C.I.Acid Blue 113 in the dyeing process of goat leathers and collected the effluent. The collected effluent was suitably diluted to achieve $30 \mathrm{ppm}$ concentration equivalent to the optimized dye concentration in order to treat the effluent using free HRP under optimized reaction parameters. $3 \mathrm{~mL}$ of the diluted tannery effluent was treated with optimized reaction parameters such as $0.08 \mathrm{U}$ of free HRP, $14 \mu \mathrm{L}$ of $\mathrm{H}_{2} \mathrm{O}_{2}$ for $45 \mathrm{~min}$ at $\mathrm{pH} 6.6$ and $30^{\circ} \mathrm{C}$. The UV-Visible absorption spectra recorded between 300 and $800 \mathrm{~nm}$ for the tannery effluent before and after free HRP treatment is shown in Figure 8. The absorbance spectrum of the tannery effluent containing the unutilized C.I.Acid Blue 113 exhibits a red-shifted absorption band

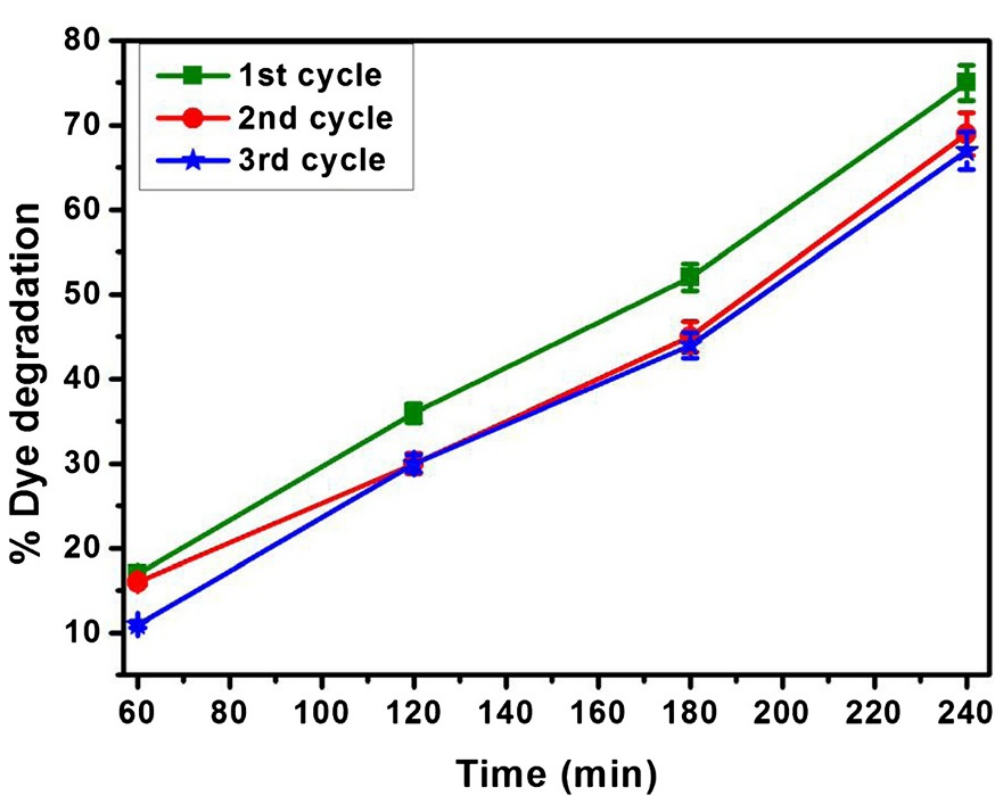

Figure 6 Recyclability of immobilized HRP for the biocatalytic color removal for 3 cycles as a function of contact time. 
(a)

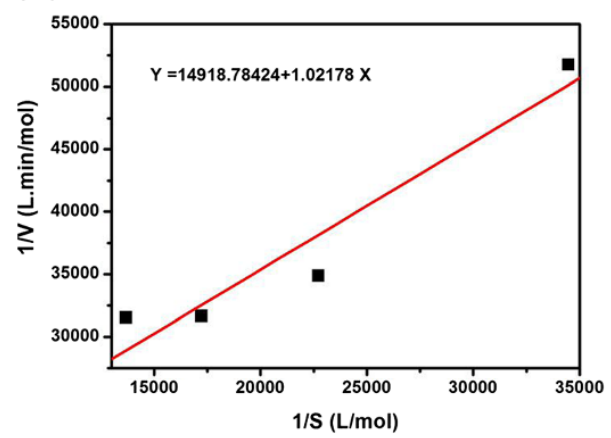

(b)

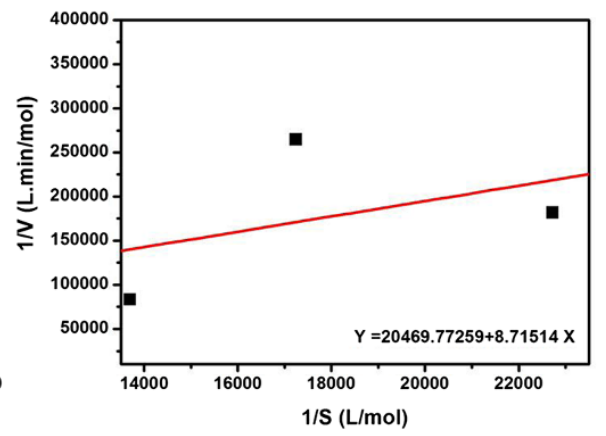

Figure 7 Lineweaver-Burk plot for the biocatalytic degradation of the dye using (a) free and (b) immobilized HRP.

with $\lambda_{\max }$ at $578 \mathrm{~nm}$ in comparison to the $\lambda_{\max }$ at $566 \mathrm{~nm}$ for pure C.I.Acid Blue 113 solution in distilled water without any chemical auxiliaries. This could be due to the fact that the tannery effluent contains not only unutilized C.I. Acid Blue 113 but also other chemicals, which can possibly interact with the dye molecule causing the red shift. The free HRP treated tannery effluent did not show any absorption band thereby demonstrating its ability to remove color from the tannery effluent. However, care should be exercised on the use of HRP in the real-time application since HRP can denature in extreme conditions such as strong acid and basic medium and high temperature (Shi et al. 2011). Although immobilized HRP can be advantageous under these extreme conditions (Alemzadeh and Nejati 2009), a semitechnical trial can be carried out before attempting industrial scale treatment.

\section{Conclusions}

The performance of both the free and immobilized HRP depends on the reaction time, $\mathrm{pH}$, temperature, HRP and $\mathrm{H}_{2} \mathrm{O}_{2}$ concentration. Ambient conditions such as room temperature $\left(30^{\circ} \mathrm{C}\right)$ and near-neutral $\mathrm{pH}(6.6)$ were suitable for the action of HRP $(0.08 \mathrm{U})$ in both the free and immobilized forms on the optimized dye concentration (30 mg/L) with the assistance of $14 \mu \mathrm{H}_{2} \mathrm{O}_{2}$. Free HRP has a faster reaction time (45 $\mathrm{min})$ than immobilized HRP $(4 \mathrm{~h})$. The latter can be recycled for at least 3 times thereby demonstrating its potential for application at industrial level. The kinetic parameters for this study are also in line with the optimization experimental results. Free HRP was used for treating actual tannery effluent and the results obtained were satisfactory. This study demonstrates a feasible method for treating tannery effluent. This method could be used to achieve a sustainable and greener environment.

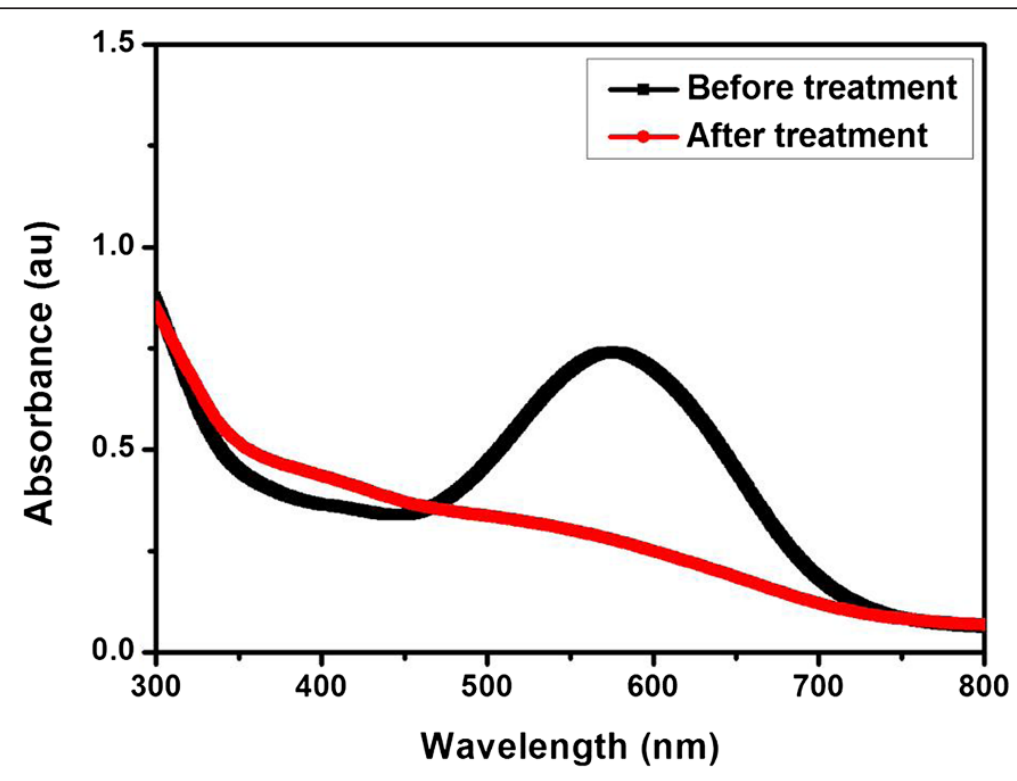

Figure 8 Absorption spectra of tannery effluent before and after treatment with the free HRP. 


\section{Additional file}

Additional file 1: For preliminary data and calculation for drawing kinetics of free HRP and drawing kinetics of immobilized HRP.

\section{Competing interests}

The authors declare they have no competing interests in relation to this article.

\section{Authors' contributions}

SP performed bench work; AA and MA designed the experiments and analyzed the data. SP and PT conceived the work, interpreted the results and co-wrote the paper. All authors read and approved the final manuscript.

\section{Acknowledgements}

PT and MA wish to thank the CSIR, New Delhi, for providing funding under the Young Scientist Award project scheme.

Received: 17 May 2013 Accepted: 19 July 2013

Published: 24 July 2013

\section{References}

Alemzadeh I, Nejati S (2009) Phenols removal by immobilized horseradish peroxidase. J Hazard Mater 66:1082-1086

Arslan M (2011) Immobilization horseradish peroxidase on amine-functionalized glycidyl methacrylate- $g$-poly (ethylene terephthalate) fibers for use in azo dye decolorization. Polym Bull 66:865-879

Gholami-Borujeni F, Mahvi AH, Nasseri S, Faramarzi MA, Nabizadeh R, Alimohammadi M (2011) Enzymatic treatment and detoxification of Acid Orange 7 from textile wastewater. Appl Biochem Biotech 165:1274-1284

Gozmen B, Kayan B, Gizir AM, Hesenov A (2009) Oxidative degradations of reactive blue 4 dye by different advanced oxidation methods. J Hazard Mater 168:129-136

Kandelbauer A, Maute O, Kessler RW, Erlacher A, Gubitz1 GM (2004) Study of dye decolorization in an immobilized laccase enzyme-reactor using online spectroscopy. Biotechnol Bioeng 87:552-563

Lachheb H, Puzenat E, Houas A, Ksibi M, Elaloui E, Guillard C, Herrmann JM (2002) Photo catalytic degradation of various types of dyes (Alizarin S, Crocein Orange G, Methyl Red, Congo Red, Methylene Blue) in water by UVirradiated titania. Appl Catal B-Environ 39:75-90

Mohan SV, Prasad KK, Rao NC, Sarma PN (2005) Acid azo dye degradation by free and immobilized horseradish peroxidase (HRP) catalyzed process. Chemosphere 58:1097-1105

Monier M, Ayad DM, Wei Y, Sarhan AA (2010) Immobilization of horseradish peroxidase on modified chitosan beads. Int J Biol Macromol 46:324-330

Murugananthan M, Raju GB, Prabhakar S (2004) Separation of pollutants from tannery effluents by electro flotation. Sep Purif Technol 40:69-75

Ollikka P, Alhonmaki K, Leppanen VM, Glumoff VM, Raijola T, Suominen I (1993) Decolorization of azo, triphenyl Methane, heterocyclic, and polymeric dyes by lignin peroxidase isoenzymes from Phanerochaete chrysosporium. Appl Environ Microb 59:4010-4016

Onder S, Celebi M, Altikatoglu M, Hatipoglu A, Kuzu H (2011) Decolorization of naphthol blue black using the horseradish peroxidase. Appl Biochem Biotech 163:433-443

Palmieri G, Cennamo G, Sannia G (2005) Remazol Brilliant Blue R decolourisation by the fungus Pleurotus ostreatus and its oxidative enzymatic system. Enzyme Microb Tech 36:17-24

Regalado C, Garcia-Almendarez BE, Duarte-Vazquez MA (2004) Biotechnological applications of peroxidases. Phytochem Rev 3:243-256

Rodriguez A, Ovejero A, Sotelo JL, Mestanza M, Garcia J (2010) Heterogeneous Fenton catalyst supports screening for mono azo dye degradation in contaminated wastewaters. Ind Eng Chem Res 49:498-505

Sauer TP, Casaril TP, Oberziner ALB, Jose HJ, Moreira RFPM (2006) Advanced oxidation processes applied to tannery wastewater containing Direct Black 38 -Elimination and degradation kinetics. J Hazard Mater B 135:274-279
Shi W, Zhang $X$, He S, Huang Y (2011) $\mathrm{CoFe}_{2} \mathrm{O}_{4}$ magnetic nanoparticles as a peroxidase mimic mediated chemiluminescence for hydrogen peroxide and glucose. Chem Commun 47:10785-10787

Ulson de Souza SMAG, Forgiarini E, Ulson de Souza AA (2007) Toxicity of textile dyes and their degradation by the enzyme horseradish peroxidase (HRP). J Hazard Mater 147:1073-1078

Wagner M, Nicell JA (2001) Peroxidase-catalyzed removal of phenols from a petroleum refinery wastewater. Water Sci Technol 43:253-260

doi:10.1186/2193-1801-2-341

Cite this article as: Preethi et al.: Probing horseradish peroxidase catalyzed degradation of azo dye from tannery wastewater. SpringerPlus 2013 2:341.

\section{Submit your manuscript to a SpringerOpen ${ }^{\circ}$ journal and benefit from:}

- Convenient online submission

- Rigorous peer review

- Immediate publication on acceptance

- Open access: articles freely available online

- High visibility within the field

- Retaining the copyright to your article

Submit your next manuscript at $>$ springeropen.com 